\title{
Isolation and recovery of microbial polyhydroxyalkanoates
}

\author{
B. Kunasundari, K. Sudesh* \\ Ecobiomaterial Research Laboratory, School of Biological Sciences, Universiti Sains Malaysia, 11800 Penang, Malaysia
}

Received 17 November 2010; accepted in revised form 18 January 2011

\begin{abstract}
The deleterious environmental impacts caused by plastic wastes have attracted worldwide concern. The biobased and biodegradable polyhydroxyalkanoate (PHA) appears to be one of the potential candidates to replace some conventional plastics. However, high production cost of PHAs has limited their market penetration. The major cost absorbing factors are the upstream fermentation processes and the downstream PHA recovery technologies. The latter significantly affects the overall process economics. Various recovery technologies have been proposed and studied in small scales in the laboratory as well as in industrial scales. These include solvent extraction, chemical digestion, enzymatic treatment and mechanical disruption, supercritical fluid disruption, flotation techniques, use of gamma irradiation and aqueous two-phase system. This paper reviews all the recovery methods known to date and compares their efficiency and the quality of the resulting PHA. Some of the large-scale production of PHA and the strategies employed to reduce the production cost are also discussed.
\end{abstract}

Keywords: biodegradable polymers, polyhydroxyalkanoate, recovery, microorganism

\section{Introduction}

The versatility of plastic materials in terms of mechanical properties and durability has been manipulated by mankind to enhance quality of life without realizing they have become increasingly ubiquitous. The world's plastics production was estimated to be 260 million tonnes in 2007 [1]. It is clear from this figure that the long term deleterious environmental impacts caused by plastics were entirely overlooked and this in turn poses greater difficulties for plastic waste disposal. Therefore, the development and use of biodegradable plastics is gaining more serious attention. The most extensively studied thermoplastic biopolymers are the polyhydroxyalkanoates (PHA) and polylactic acid (PLA) [2]. PHA is attractive because of its biodegradability and physical properties that closely resemble some conventional plastics such as polypropylene (PP) and low-density polyethylene (LDPE) [3]. In addition, because of the diverse types of monomers (about 150 different structures), it is possible to produce PHA copolymers having a wide range of properties. The various PHA monomers can be classified based on the number of carbon atoms as short-chain length PHA (scl-PHA), medium-chain length PHA (mcl-PHA) and long-chain length PHA (1cl-PHA). Scl-PHA refers to PHA comprised of monomers having 5 or less carbon atoms. These include 3-hydroxybutyrate and 3-hydroxyvalerate. The mcl-PHA is comprised of monomers having 6 to 14 carbon atoms. These include 3-hydroxyhexanoate, 3-octanoate and 3-hydroxydecanoate. The 1cl-PHA, which is uncommon and least studied, consists of monomers with more than 14 carbon atoms. Recently, it has also been made possible to synthesize a new type of PHA containing lactide as a co-monomer [4-6]. All these developments indicate that PHA may become the preferred next generation bioplastic. However, to date the market penetration of PHA is still scarce. This is mainly due to

\footnotetext{
${ }^{*}$ Corresponding author, e-mail: ksudesh@usm.my
}

(c) BME-PT 
its high production cost. The main reasons behind the economic disadvantages are the costly fermentation and purification technologies. The latter significantly affects the overall process economics. Much work has been carried out to lower the PHA production cost by the use of effective and inexpensive carbon source and genetically engineered microorganisms. Sugars have been shown to be an effective feedstock for PHA production in Brazil, especially when the PHA production is integrated to the sugarcane-processing factory [7]. On the other hand, it has been demonstrated that vegetable oils are also potential feedstock for PHA production [812] in countries like Malaysia where palm oil is produced in very large scales. High levels of PHA

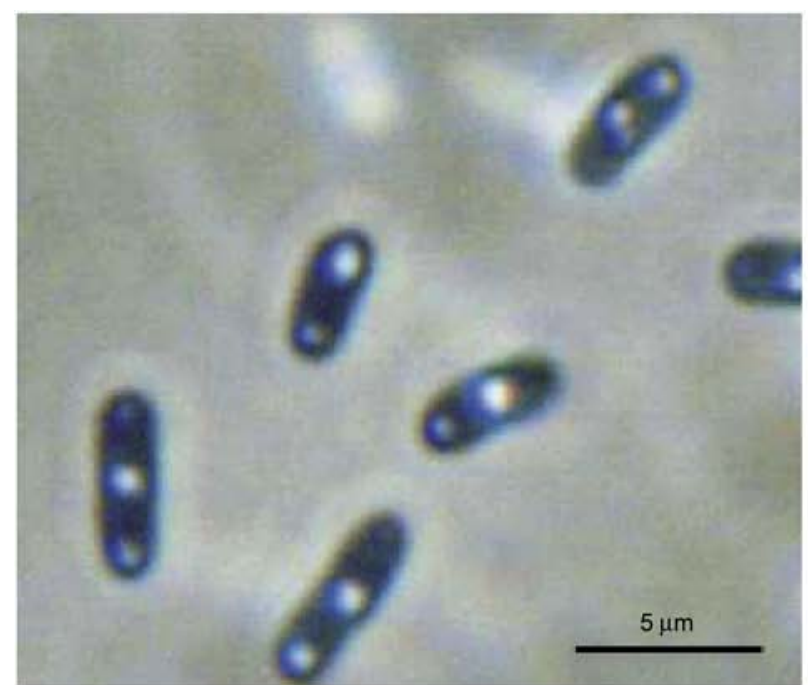

a)

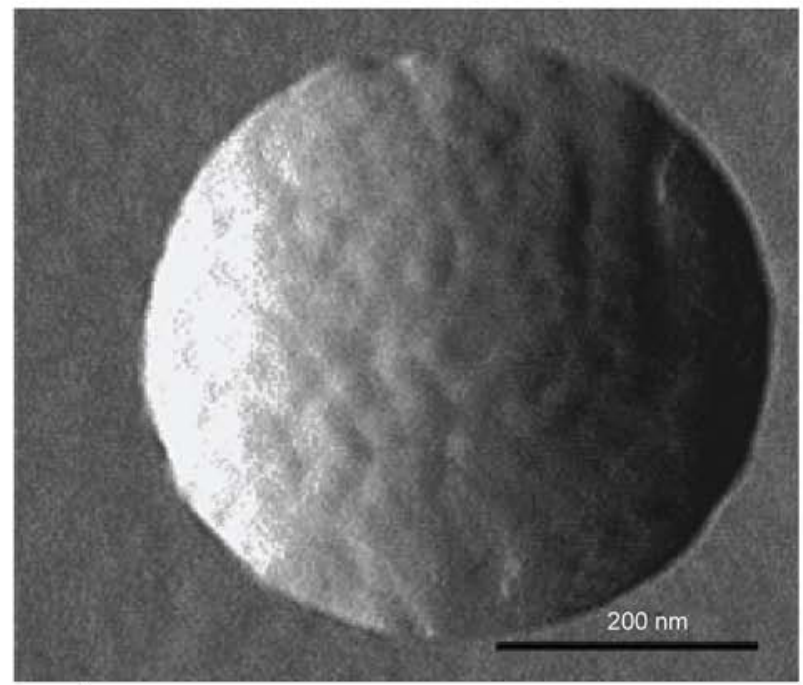

c) accumulation have been achieved using crude palm kernel oil. The yield of PHA from vegetable oils is at least two times the yield of PHA from sugars [13]. However, the real cost associated with PHA would only diminish with the development of a cheaper and environmentally friendly PHA recovery method. This article reviews the currently known methods for the recovery of PHA. Some of the large-scale production of PHA and the strategies employed to reduce the production cost are also discussed.

\section{PHA biosynthesis}

PHA is a lipid-like compound synthesized by many microorganisms as a form of storage material. Upon

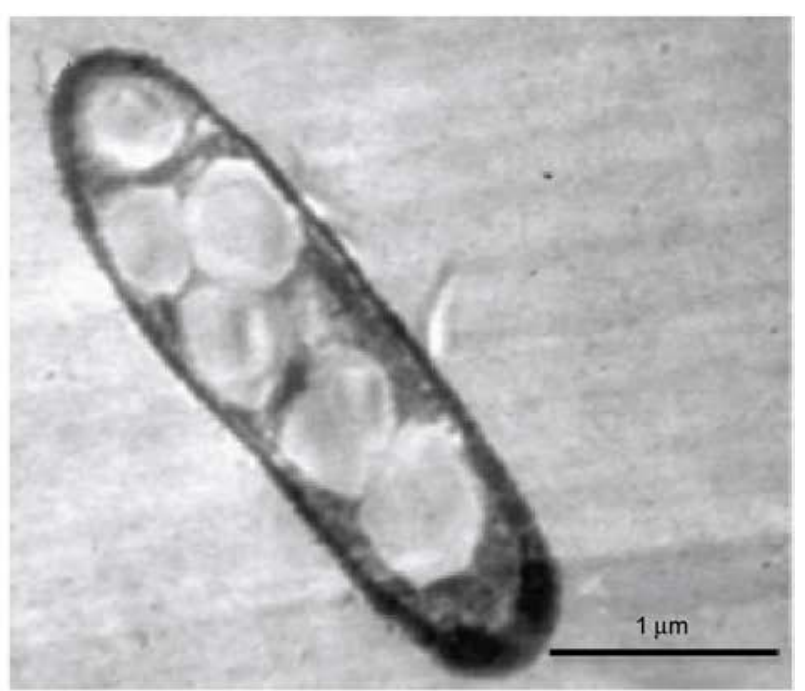

b)

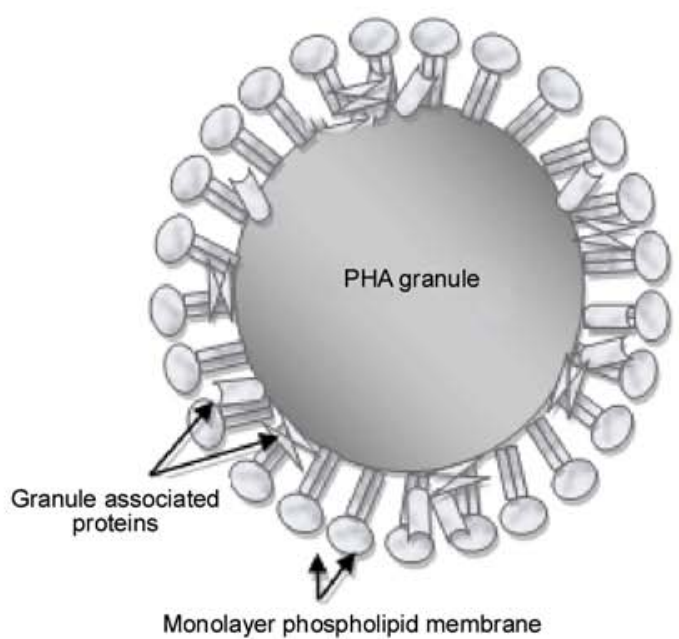

d)

Figure 1. Morphology of PHA granules in the bacterial cells observed under (a) Phase contrast and (b) Transmission Electron Microscope. (c) Atomic force microscope deflection image showing the presence of globular particles on the granule surface. (d) A model representing the native PHA granule with a protein monolayer on the surface (Not drawn according to actual scale) 
synthesis, PHA is accumulated in the form of granules in the bacterial cell cytoplasm. The average size of the PHA granules is approximately $0.2-$ $0.5 \mu \mathrm{m}$ (Figure 1). Figure 1 shows the morphology of PHA granules when observed using various microscopy techniques. Atomic force microscopy analysis has shown the presence of a protein monolayer on the surface of PHA granules [14-15]. In order to recover the PHA granules, it is necessary to rupture the bacterial cell and remove the protein layer that coats the PHA granules. Alternatively, the PHA has to be selectively dissolved in a suitable solvent. Formation of PHA granules is dependent on the presence of suitable metabolic pathways. Figure 2 shows a simplified metabolic pathway for the biosynthesis of poly(3-hydroxybutyrate) $[\mathrm{P}(3 \mathrm{HB})]$, which is the most common type of PHA. The biosynthesis of $\mathrm{P}(3 \mathrm{HB})$ is initiated by the condensation of two acetyl-CoA molecules by $\beta$-ketothiolase (PhaA) to form acetoacetyl-CoA. Subsequently, NADPH-dependent acetoacetyl-CoA reductase (PhaB) catalyzes the reduction of acetoacetyl-CoA to the (R)-isomer of 3-hydroxybutyryl-CoA which is then polymerized into $\mathrm{P}(3 \mathrm{HB})$ by the PHA synthase (PhaC) [3]. To date, Cupriavidus necator (formerly known as Wautersia eutropha, Ralstonia eutropha and Alcaligenes eutrophus) is the most extensively studied microorganism for the cost-effective production of PHA. Numerous other strains such as Bacillus cereus SPV, Sinorhizobium meliloti, Azotobacter chroococcum G-3, Pseudomonas putida KT2440 and Metylobacterium sp V49 also gaining attention for the PHA production. Besides wild-type strains, recombinant strains are also being devel-

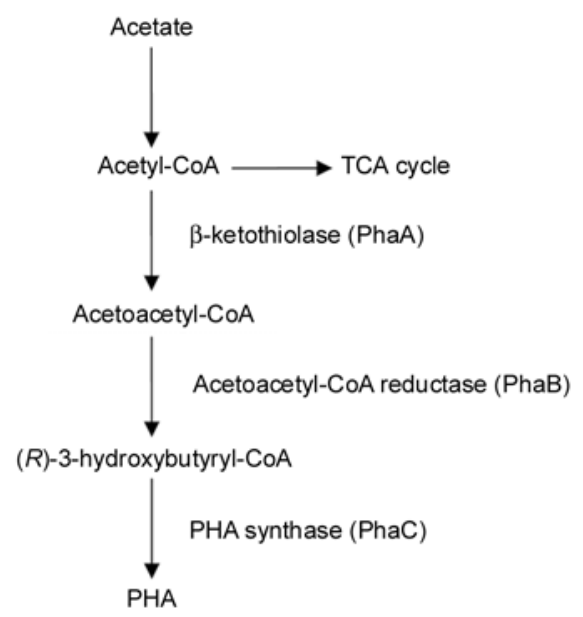

Figure 2. The most studied metabolic pathway for the biosynthesis of polyhydroxyalkanoates (PHA) oped. Various types of recombinant Escherichia coli strains are able to synthesize PHA to high intracellular level and some are amenable to genetically mediated lysis system to facilitate the release of the PHA granules [16]. Compared to the extensive research on the biosynthesis of PHA, research on the downstream processing of PHA is scarce. Table 1 shows the various extraction methods that have been reported. The following section will describe all these methods and finally compare their advantages and disadvantages (Table 2). This study is important to choose a suitable method that could effectively isolate PHA from the microbial cells.

\section{Recovery techniques for the isolation and purification of PHA from microbial cells}

\subsection{Solvent extraction}

Solvent extraction is the most extensively adopted method to recover PHA from the cell biomass (Table 1). This method is also used routinely in the laboratory because of its simplicity and rapidity. Two main steps are involved, first is the modification of cell membrane permeability thus allowing release and solubilization of PHA. This is then followed by non-solvent precipitation [17]. Extraction of PHA with solvents such as chlorinated hydrocarbons, i.e. chloroform, 1,2-dichloroethane [18] or some cyclic carbonates like ethylene carbonate and 1,2-propylene carbonate [19] is common. Lower chain ketone such as acetone is the most prominent solvent especially for the extraction of mcl-PHA [20]. Precipitation of PHA is commonly induced by non-solvent such as methanol and ethanol [18]. Solvent extraction has undoubted advantages over the other extraction methods of PHA in terms of efficiency. This method is also able to remove bacterial endotoxin and causes negligible degradation to the polymers [17]. So, it is possible to obtain very pure PHA with high molecular weights. Unfortunately, large-scale application of solvent extraction is generally viewed as a method that is not environmentally friendly. In addition, several other factors discourage the use of solvents such as high capital and operational costs. Another problem is the high viscosity of the extracted polymer solution when the $\mathrm{P}(3 \mathrm{HB})$ concentration exceeds $5 \%(\mathrm{w} / \mathrm{v})$ (Table 2$)$. The viscosity of the solution interferes with cell debris removal resulting in lengthy separation process. Besides, there is a possibility that solvent 
Table 1. Various PHA recovery methods that have been reported

\begin{tabular}{|c|c|c|c|c|}
\hline Extraction method & Comments & Strain & Results & Reference \\
\hline \multirow[t]{8}{*}{ Solvent extraction } & Chloroform & Bacillus cereus SPV & Purity: $92 \%$; Yield: $31 \%$ & Valappil et al. [31] \\
\hline & Chloroform & $\begin{array}{l}\text { Cupriavidus necator } \\
\text { DSM } 545\end{array}$ & Purity: 95\%; Yield: 96\% & Fiorese et al. [25] \\
\hline & 1,2-Propylene carbonate & C. necator DSM 545 & Purity: $84 \%$; Yield:95\% & Fiorese et al. [25] \\
\hline & Acetone-water process & & Yield: $80-85 \%$ & Narasimhan et al. [65] \\
\hline & Methyl tert-butyl ether & $\begin{array}{l}\text { Pseudomonas putida } \\
\text { KT2440 }\end{array}$ & Yield: $15-17.5 \mathrm{wt} \%$ & Wampfler et al. [26] \\
\hline & Methylene chloride & C. necator & Purity: $98 \%$ & Zinn et al. [66] \\
\hline & $\begin{array}{l}\text { Non halogenated solvents- } \\
\text { isoamy propionate, propyl } \\
\text { butyrate, isoamyl valerat etc. }\end{array}$ & C. necator & & $\begin{array}{l}\text { Mantelatto and Durao } \\
\text { [67] }\end{array}$ \\
\hline & Acetone, room temperature & P. putida GPo1 & Yield: 94\% & $\begin{array}{l}\text { Elbahloul and Stein- } \\
\text { büchel [64] }\end{array}$ \\
\hline \multicolumn{5}{|l|}{ Digestion method } \\
\hline \multirow[t]{2}{*}{ Surfactant } & SDS & $\begin{array}{l}\text { Recombinant } \\
\text { Escherichia coli }\end{array}$ & Purity: 99\%; Yield:89\% & Choi and Lee [54] \\
\hline & Palmitoyl carnitine & \begin{tabular}{|l|} 
C. necator, \\
Alcaligenes latus
\end{tabular} & $\begin{array}{l}\text { Degree of lysis: } 56- \\
78 \%\end{array}$ & Lee et al. [68] \\
\hline \multirow[t]{2}{*}{ Sodium hypochlorite } & Sodium hypochlorite & $\begin{array}{l}\text { C. necator, } \\
\text { Recombinant E. coli }\end{array}$ & $\begin{array}{l}\text { Purity: } 86 \% \\
\text { Purity: } 93 \%\end{array}$ & Hahn et al. [69] \\
\hline & Sodium hypochlorite & C. necator DSM 545 & Purity: $98 \%$ & Berger et al. [70] \\
\hline \multirow[t]{2}{*}{$\begin{array}{l}\text { Surfactant-sodium } \\
\text { hypochlorite }\end{array}$} & SDS-Sodium hypochlorite & $\begin{array}{l}\text { Azotobacter chroococ- } \\
\text { cum G-3 }\end{array}$ & Purity: $98 \%$; Yield: $87 \%$ & Dong and Sun [28] \\
\hline & $\begin{array}{l}\text { Triton X-100-sodium } \\
\text { hypochlorite }\end{array}$ & C. necator DSM 545 & Purity: 98\% & Ramsay et al. [27] \\
\hline \multirow[t]{2}{*}{ Surfactant-Chelate } & Triton X-100-EDTA & Sinorhizobium meliloti & Purity: $68 \%$ & $\begin{array}{l}\text { Lakshman and Shamala } \\
\text { [34] }\end{array}$ \\
\hline & Betaine-EDTA disodium salt & C. necator DSM 545 & $\begin{array}{l}\text { Purity: > 96\%; Yield: } \\
90 \%\end{array}$ & Chen et al. [33] \\
\hline \multirow{2}{*}{$\begin{array}{l}\text { Dispersion of sodium } \\
\text { hypochlorite and chloro- } \\
\text { form }\end{array}$} & $\begin{array}{l}\text { Chloroform- sodium } \\
\text { hypochlorite }\end{array}$ & B. cereus SPV & Purity: 95\%; Yield: $30 \%$ & Valappil et al. [31] \\
\hline & $\begin{array}{l}\text { Chloroform- sodium } \\
\text { hypochlorite }\end{array}$ & $\begin{array}{l}\text { C. necator, } \\
\text { Recombinant E. coli }\end{array}$ & Purity: $>98 \%$ & Hahn et al. [69] \\
\hline $\begin{array}{l}\text { Selective dissolution by } \\
\text { protons }\end{array}$ & Sulfuric acid & C. necator & $\begin{array}{l}\text { Purity: >97\%; Yield: > } \\
95 \%\end{array}$ & Yu and Chen [21] \\
\hline \multirow[t]{3}{*}{ Enzymatic digestion } & $\begin{array}{l}\text { Microbispora sp culture-chlo- } \\
\text { roform }\end{array}$ & S. meliloti & Purity: $94 \%$ & $\begin{array}{l}\text { Lakshman and Shamala } \\
\text { [34] }\end{array}$ \\
\hline & $\begin{array}{l}\text { Enzyme combined with SDS- } \\
\text { EDTA }\end{array}$ & P. putida & Purity: 93\% & Kathiraser et al. [71] \\
\hline & Bromelain; pancreatin & C. necator & $\begin{array}{l}\text { Purity: } 89 \% \text {; Purity: } \\
90 \%\end{array}$ & Kapritchkoff et al. [39] \\
\hline \multirow[t]{4}{*}{ Mechanical disruption } & Bead mill & A. latus & & Tamer et al. [23] \\
\hline & High pressure homogenization & A. latus & & Tamer et al. [23] \\
\hline & $\begin{array}{l}\text { SDS-High pressure homoge- } \\
\text { nization }\end{array}$ & Metylobacterium sp V49 & Purity: $95 \%$; Yield: $98 \%$ & Ghatnekar et al. [48] \\
\hline & Sonication & Bacillus flexus & Purity: $92 \%$; Yield: $20 \%$ & Divyashree et al. [37] \\
\hline Supercritical fluid & $\mathrm{SC}-\mathrm{CO}_{2}$ & C. necator & Yield: $89 \%$ & Hejazi et al. [49] \\
\hline \multirow[t]{3}{*}{ Cell fragility } & Chloroform & B. flexus & Yield: $43 \%$ & $\begin{array}{l}\text { Divyashree and } \\
\text { Shamala [56] }\end{array}$ \\
\hline & Sodium hypochlorite & B. flexus & Yield: $50 \%$ & $\begin{array}{l}\text { Divyashree and } \\
\text { Shamala [56] }\end{array}$ \\
\hline & Alkaline hydrolysis & B. flexus & Yield: $50 \%$ & $\begin{array}{l}\text { Divyashree and } \\
\text { Shamala [56] }\end{array}$ \\
\hline $\begin{array}{l}\text { Self flotation of cell } \\
\text { debris }\end{array}$ & Chloroform & $\begin{array}{l}\text { Zobellella denitrificans } \\
\text { MW1 }\end{array}$ & Purity: 98\%; Yield: $85 \%$ & $\begin{array}{l}\text { Ibrahim and Steinbüchel } \\
\text { [57] }\end{array}$ \\
\hline Dissolved air flotation & $\begin{array}{l}\text { Enzymatic hydrolysis, sonifi- } \\
\text { cation, flotation }\end{array}$ & P. putida & Purity: $86 \%$ & van Hee et al. [58] \\
\hline $\begin{array}{l}\text { Aqueous two phase sys- } \\
\text { tem }\end{array}$ & Microbispora sp culture-ATPS & B. flexus & Purity: 95\%; Yield: 50\% & Divyashree et al. [37] \\
\hline Gamma irradiation & Radiation-chloroform & B. flexus & Yield: $45-54 \%$ & $\begin{array}{l}\text { Divyashree and } \\
\text { Shamala [61] }\end{array}$ \\
\hline Air classification & & $\begin{array}{l}\text { E. coli } \\
\text { C. necator }\end{array}$ & $\begin{array}{l}\text { Purity: 97\%; Yield: } 90 \% \\
\text { Purity: 95\%; Yield: } 85 \%\end{array}$ & $\begin{array}{l}\text { Noda [72] } \\
\text { Noda [72] }\end{array}$ \\
\hline Spontaneous liberation & & E. coli & Autolysis of $80 \%$ & Jung et al. [73] \\
\hline
\end{tabular}


Table 2. Comparison of the advantages and disadvantages of various PHA extraction methods

\begin{tabular}{|c|c|c|}
\hline Recovery method & Advantages & Disadvantages \\
\hline Solvent extraction & $\begin{array}{l}\text { Removal of endotoxin } \\
\text { Useful for medical applications } \\
\text { High purity } \\
\text { Negligible/limited degradation to the polymer } \\
\text { Higher molecular weight }\end{array}$ & $\begin{array}{l}\text { Not environmentally friendly } \\
\text { Consumption of large volume of toxic and volatile } \\
\text { solvents } \\
\text { High capital and operation cost } \\
\text { Difficulty in extracting PHA from solution containing } \\
\text { more than } 5 \%(w / v) \text { P }(3 \mathrm{HB}) \\
\text { Lengthy process } \\
\text { Native order of polymer chains in PHA granules } \\
\text { might be disrupted }\end{array}$ \\
\hline $\begin{array}{l}\text { Chemical Digestion } \\
\text { Surfactant }\end{array}$ & $\begin{array}{l}\text { Extracted PHA retains original molecular weight } \\
\text { Native order of polymer chains in PHA granules is } \\
\text { retained }\end{array}$ & $\begin{array}{l}\text { Low purity of PHA } \\
\text { Treatment required to remove surfactant from waste- } \\
\text { water }\end{array}$ \\
\hline Sodium hypochlorite & Higher purity of PHA can be obtained & $\begin{array}{l}\text { Severe reduction in molecular weight of the extracted } \\
\text { PHA }\end{array}$ \\
\hline $\begin{array}{l}\text { Sequential surfactant- } \\
\text { hypochlorite }\end{array}$ & $\begin{array}{l}\text { High quality of PHA } \\
\text { Rapid recovery and simple process } \\
\text { Retain native order of polymer chains in PHA gran- } \\
\text { ules } \\
\text { Lower operating cost compared to solvent extraction }\end{array}$ & $\begin{array}{l}\text { Combined cost of surfactant and sodium hypochlorite } \\
\text { Wastewater treatment required to remove residual sur- } \\
\text { factant and sodium hypochlorite }\end{array}$ \\
\hline $\begin{array}{l}\text { Dispersion sodium } \\
\text { hypochlorite and sol- } \\
\text { vent extraction }\end{array}$ & $\begin{array}{l}\text { High purity of PHA } \\
\text { Reduced viscosity of solvent phase due to digestion of } \\
\text { non-polymer cellular material (NPCM) by sodium } \\
\text { hypochlorite }\end{array}$ & $\begin{array}{l}\text { Not environmentally friendly } \\
\text { Consumption of large volume of toxic and volatile } \\
\text { solvents } \\
\text { Higher recovery cost }\end{array}$ \\
\hline Surfactant-chelate & $\begin{array}{l}\text { Convenient operation } \\
\text { High quality of product }\end{array}$ & Produce large volume of wastewater \\
\hline $\begin{array}{l}\text { Selective dissolution of } \\
\text { NPCM by protons }\end{array}$ & $\begin{array}{l}\text { Low operating cost } \\
\text { Higher recovery yield }\end{array}$ & $\begin{array}{l}\text { Severe reduction in molecular weight if the process } \\
\text { parameters are not controlled stringently }\end{array}$ \\
\hline Enzymatic digestion & $\begin{array}{l}\text { Mild operation conditions } \\
\text { Good recovery with good quality }\end{array}$ & $\begin{array}{l}\text { Complex process } \\
\text { High cost of enzymes }\end{array}$ \\
\hline Bead mill & $\begin{array}{l}\text { No chemicals used } \\
\text { Less contamination } \\
\text { Not susceptible to blockages } \\
\text { No micronization of PHA granules }\end{array}$ & $\begin{array}{l}\text { Require several passes } \\
\text { Long processing time } \\
\text { Various process parameters have to be controlled pre- } \\
\text { cisely }\end{array}$ \\
\hline $\begin{array}{l}\text { High pressure homoge- } \\
\text { nization }\end{array}$ & $\begin{array}{l}\text { No chemicals used } \\
\text { Less contamination }\end{array}$ & $\begin{array}{l}\text { Severe micronization of PHA granules } \\
\text { Depends on both process and microbial physiological } \\
\text { parameters } \\
\text { Possible for thermal degradation of desired products } \\
\text { Formation of fine cellular debris that interfere with } \\
\text { downstream processing }\end{array}$ \\
\hline $\begin{array}{l}\text { Supercritical fluid } \\
\text { (SCF) }\end{array}$ & $\begin{array}{l}\text { Simple } \\
\text { Inexpensive } \\
\text { Rapid } \\
\text { Environmentally friendly }\end{array}$ & $\begin{array}{l}\text { Dependent on process parameters } \\
\text { Frequent need for clean up } \\
\text { Difficulties in extracting polar analytes } \\
\text { Difficulties in dealing with natural samples }\end{array}$ \\
\hline Cell fragility & $\begin{array}{l}\text { Simple recovery method } \\
\text { Mild extraction conditions }\end{array}$ & $\begin{array}{l}\text { Need to balance cell wall softening and cell wall } \\
\text { integrity }\end{array}$ \\
\hline Self-flotation & Cost effective as additional steps could be avoided & $\begin{array}{l}\text { Consumption of large volume of toxic and volatile } \\
\text { solvents }\end{array}$ \\
\hline Dissolved-air flotation & $\begin{array}{l}\text { No chemicals used } \\
\text { Less contamination }\end{array}$ & Requires several consecutive flotation steps \\
\hline $\begin{array}{l}\text { Aqueous two phase sys- } \\
\text { tem (ATPS) }\end{array}$ & $\begin{array}{l}\text { Short processing time } \\
\text { Low material cost } \\
\text { Low energy consumption } \\
\text { Good resolution } \\
\text { High yield and a relatively high capacity }\end{array}$ & $\begin{array}{l}\text { Dependent on process parameters } \\
\text { Issue of robustness and reproducibility } \\
\text { Absence of commercial kits to evaluate ATPS at } \\
\text { bench scale } \\
\text { Poor understanding of the mechanism }\end{array}$ \\
\hline Gamma irradiation & $\begin{array}{l}\text { Retention of solvent solubility due to the low degree } \\
\text { of cross-linking } \\
\text { No chemicals used/Less contamination }\end{array}$ & $\begin{array}{l}\text { Length of irradiation time } \\
\text { High initial investment cost }\end{array}$ \\
\hline
\end{tabular}

extraction may disrupt the unique nascent state of the $\mathrm{P}(3 \mathrm{HB})$ granules that maybe useful in certain applications. In case of accidents, the potential release of a large amount of highly toxic and volatile solvents to the environment is also of great concern
[17, 21-23]. Therefore, 1,2-propylene carbonate has been proposed as an alternative to halogenated solvents in the recovery process of PHA [24-25]. Higher boiling point $\left(240^{\circ} \mathrm{C}\right)$ of 1,2-propylene carbonate prevents the evaporation to the environment 
at lower temperatures and allows its reusability for several cycles of purification. This could reduce the solvent consumption and therefore it is viewed as economically advantageous. Besides, 1,2-propylene carbonate is considered safe due to its low toxicity. It is widely used in many applications including cosmetics [24]. Fiorese et al. [25] reported a maximum PHA yield of $95 \%$ and a purity of $84 \%$ when extracted from the C. necator cells at $130^{\circ} \mathrm{C}$ for 30 min without involving any pretreatment. This is comparable to the values obtained from chloroform extraction ( $94 \%$ yield and $98 \%$ purity). For the extraction of mcl-PHA, methyl tert-butyl ether (MTBE) has been evaluated and the extractability was found to be promising as in the case with chlorinated-solvents [26]. Wampfler et al. [26] claimed that MTBE would have lower environmental impact if the recovery of PHA as well as the production and recycling of MTBE could be carried out in closed facilities.

\subsection{Digestion methods}

While solvent extraction techniques involve the solubilization of the PHA granules, digestion methods involve the solubilization of the cellular materials surrounding the PHA granules. Digestion methods are well established approaches developed as an alternative to solvent extraction and can be classified into either chemical digestion or enzymatic digestion. Because of the ready availability of various chemicals with known properties many studies have been directed towards the development of chemical digestion methods compared to enzymatic digestion.

\subsubsection{Chemical digestion}

Various chemical digestion methods have been evaluated for the recovery PHA from cellular biomass (Table 1). The approach is based on the solubilization of non-PHA cellular mass (NPCM) and mainly utilizes sodium hypochlorite or surfactants. The important features of sodium hypochlorite such as strong oxidizing properties and non-selectivity can be manipulated to digest NPCM and facilitate PHA recovery [21]. A range of surfactants has been evaluated such as sodium dodecyl sulfate (SDS), Triton X-100, palmitoyl carnitine, betaine and among them, SDS showed good performance. However, the quality of PHA obtained using either surfactant or sodium hypochlorite alone was not good enough (Table 2). Therefore, a combination of surfactantsodium hypochlorite was used [22]. Isolation of PHA granules by surfactant digestion exhibited lower degree of purity but had slightly higher molecular weight than sodium hypochlorite digestion (Table 2). In contrast, PHA of higher purity was obtained using sodium hypochlorite but with severe degradation of molecular weight up to $50 \%$ [27]. Sequential surfactant-hypochlorite treatment promoted better and rapid recovery of PHA [27-28] and resulted in 50\% reduction of overall cost when compared to solvent extraction [22]. Yet, the low operating cost [17] and technical simplicity of this process are not complemented by the complex and unresolved problems caused by surfactant in wastewater treatment and relatively high cost of chemical agents such as SDS and sodium hypochlorite (Table 2) [22]. Hahn and co-researchers established a separation process that took advantage of both differential digestion and solvent extraction [29-30]. The hydrophobicity of $\mathrm{P}(3 \mathrm{HB})$ and hydrophilicity of lyophilized cells accounted for the development of dispersions of a sodium hypochlorite solution and chloroform. A study by Valappil et al. [31] described that the high molecular weight of $\mathrm{P}(3 \mathrm{HB})$ could be retained by using this method. The main limitation is the use of large quantity of solvent that would raise the recovery cost (Table 2). Surfactant-chelate digestion system was also explored to improve cell disruption and to increase the rate of PHA release [32]. Use of recycled wastewater was proposed later as this system produced large volume of wastewater [33]. Surfactant-chelate digestion (Triton X-100 and ethylenediaminetetraacetic acid [EDTA]) could isolate PHA with $90 \%$ purity from enzymatically hydrolyzed cells of S. meliloti [34]. Another method is the selective dissolution of non-PHA cell mass by protons to enhance PHA recovery [21-22]. This method is comprised of few steps, but the most important is the solubilization of NPCM in an acidic solution to release partially crystallized PHA granules and later subjecting the suspension to decolorization in a bleaching solution. This method was claimed to lower the recovery cost by using cheaper chemicals with higher recovery efficiency. However, the process parameters have to be controlled stringently if the molecular weight is to be maintained at a minimum of $50 \%$ the original molecular 
weight. The $\mathrm{P}(3 \mathrm{HB})$ granules recovered by this method was reported to be highly crystalline.

\subsubsection{Enzymatic digestion}

Recovery process of PHA using enzymatic digestion involves a rather complex procedure (Table 1). Solubilization of cell components other than PHA typically consists of heat treatment, enzymatic hydrolysis and surfactant washing [35]. To date, various types of enzymes, especially proteases, have been evaluated for their efficiency in causing cell lysis [36]. Lakshman and Shamala [34] used Microbispora sp. culture, which was identified to secrete protease, in the fermented broth of $S$. meliloti containing $50 \%$ of PHA to induce hydrolysis. The culture was introduced to the thermally $\left(80^{\circ} \mathrm{C}\right.$ for $10 \mathrm{~min}$ ) inactivated biomass of $S$. meliloti and incubated for $72 \mathrm{~h}$. The $S$. meliloti cells were hydrolyzed by the protease resulting in the release of the intracellular components together with the PHA granules. The culture containing the lysed cells was then subjected to a simple filtration process and PHA of $94 \%$ purity was recovered using chloroform extraction. In contrast, PHA with only $66 \%$ purity was isolated from the undigested cells by using chloroform extraction. Similar study was conducted recently with a different strain by Divyashree et al. [37]. Microbispora sp. culture mixed with Bacillus flexus and subjected to separation by aqueous two phase system (ATPS) resulted in PHA with 92\% purity. The enzyme technique is attractive because of its mild operation conditions (Table 2) [38-39]. Because enzymes are very specific with respect to the reactions they catalyze, recovery of PHA with good quality could be expected. Nevertheless, the high cost of enzymes and complexity of the recovery process outweigh its advantages [39].

\subsection{Mechanical disruption}

Mechanical cell disruption is widely used to liberate intracellular protein [40]. The concept has been tested to recover PHA from bacterial cells [23]. Among the various mechanical disruption methods, bead milling and high-pressure homogenization dominate the large scale cell disruption in pharmaceutical and biotechnology industries [41]. Unlike other recovery methods, mechanical disruption is favored mainly due to economic advantageous and because it causes mild damage to the products [23].
Mechanical disruption of cells does not involve any chemicals so it minimizes environmental pollution [17] and contamination to the products [23]. In general, the drawbacks of mechanical disruption method are, high capital investment cost, long processing time and difficulty in scaling up [42-43].

\subsubsection{Bead mill}

The principle of bead mills is based on the shearing action and energy transfer from beads to cells in the contact zones (Table 1). The key parameters that affect the disruption process are the bead loading and bead diameter [38]. Tamer et al. [23] reported that with bead diameter of $512 \mu \mathrm{m}$ and $2800 \mathrm{rpm}$ agitation speed, complete disruption of the Alcaligenes latus cells was achieved after eight passes when the loading was $85 \%$ compared to loading of $75 \%$ that required more than 16 passes to release most of the cellular protein. The extent of cell disruption also depends on numerous parameters such as residence time distribution (RTD), shear forces, type of microorganisms, cell concentration, feed rate of the suspension, agitator speed, geometry of the grinding chamber and design of the stirrer [44]. Bead mills disruption was recommended for PHA recovery as it requires less power supply, not susceptible to blockages and different diameter of beads did not significantly affect the disruption rate although micronization of $\mathrm{P}(3 \mathrm{HB})$ is possible with smaller bead size [23]. The major concern is that large number of factors has to be considered to establish a good bead mill disruption system (Table 2) [44].

\subsubsection{High pressure homogenization}

With high pressure homogenization, disruption of cell suspension occurs under high pressure through an adjustable, restricted orifice discharge valve (Table 1) [45]. Process parameters such as operating pressure, number of passes, suspension temperature and homogenizer valve design must be carefully scrutinized for efficient disruption [46-47]. It was reported that less efficient recovery of $\mathrm{P}(3 \mathrm{HB})$ from A. latus was obtained with homogenizer compared to bead mill disruption due to severe micronization [23]. Nevertheless, $\mathrm{P}(3 \mathrm{HB})$ with $95 \%$ purity and $98 \%$ yield was recovered from $5 \%(\mathrm{w} / \mathrm{v})$ SDS pretreated Methylobacterium sp V49 cells subjected to homogenization at an operating pressure $400 \mathrm{~kg} \cdot \mathrm{cm}^{-2}$ after two cycles [48]. Process parame- 
ters are not the only factors that influence the cell disruption but microbial physiological parameters, namely type and growth phase of the microorganisms as well as cell concentration also affect the disruption efficiency (Table 2). Generally, Gram-positive bacteria are more difficult to be disrupted compared to Gram-negative bacteria [47]. Among the drawbacks associated with high pressure homogenization include the possibility of thermal degradation of desired products [48] and formation of fine cellular debris that would interfere with the further downstream processing of PHA granules [46].

\subsection{Supercritical fluid (SCF)}

Supercritical fluids (SCF) have emerged as a potential extraction technique in the areas of PHA recovery (Table 1) [49-51]. The unique physicochemical properties of SCF such as high density and low viscosities proposed them as suitable extraction solvents [49]. The advantages offered by SCF have led to its popularity (Table 3). Supercritical-carbon dioxide $\left(\mathrm{SC}-\mathrm{CO}_{2}\right)$ is the most predominantly used SCF due to its low toxicity and reactivity, moderate critical temperature and pressure $\left(31^{\circ} \mathrm{C}\right.$ and $\left.73 \mathrm{~atm}\right)$, availability, low cost, and non-flammability [49]. By using this method, $\mathrm{P}(3 \mathrm{HB})$ recovery of $89 \%$ from $C$. necator at $200 \mathrm{~atm}, 40^{\circ} \mathrm{C}$ and $0.2 \mathrm{ml}$ of methanol was reported [49]. Besides, there is a patent literature which describes on the purification of biopolymers such as rubber from plant material using SCF [52]. Although, the recovery obtained are comparable to other methods, it has to be highlighted that $\mathrm{SC}-\mathrm{CO}_{2}$ efficiency in bacterial cell disruption is very much dependent on the process parameters such as operating pressure, temperature, type of modifier as well as culture cultivation time (Table 2) [53]. High temperature and pressure significantly influence the physiological properties of cell membrane that prevent the biopolymer from being extracted. The addition of modifier plays an important role in increasing the polarity of the $\mathrm{CO}_{2}$ therefore suitable modifier should be selected to enhance the cell wall permeability. Matured cells are difficult to be disrupted compared to those in earlyexponential phase as new proteins would be synthesized increasing the cell resistance to disruption. In order to make the process more economically viable, Khosravi-Darani et al. [53] investigated on a series of pretreatment to improve the $\mathrm{SC}-\mathrm{CO}_{2}$ disruption. They found that with $1 \%(\mathrm{v} / \mathrm{v})$ toluene as a modifier, 200 bar of pressure, $30^{\circ} \mathrm{C}$ temperature and two times $\mathrm{SC}-\mathrm{CO}_{2}$ pressure release, up to $81 \% \mathrm{P}(3 \mathrm{HB})$ recovery could be achieved by using wet cells of C. necator. To further improve the purity of the $\mathrm{P}(3 \mathrm{HB})$, chemical pretreatment with $0.4 \%(\mathrm{w} / \mathrm{w})$ sodium hydroxide $(\mathrm{NaOH})$ was employed. The proposed recovery process of PHA is more economical as the costly freeze drying step could be avoided.

Table 3. Summary of supercritical fluids (SCF) cell disruption

\begin{tabular}{|c|c|c|c|}
\hline Extraction method & Advantages & Disadvantages & References \\
\hline $\begin{array}{l}\text { Supercritical fluid } \\
\text { (SCF) }\end{array}$ & $\begin{array}{l}\text { Simple, inexpensive } \\
\text { Rapid } \\
\text { Environmentally friendly } \\
\text { Fluid solvation power } \\
\text { Minimizes equipment and labor needs, } \\
\text { contamination and loss of yield } \\
\text { Solution for drastic problems related to } \\
\text { - non-thermal cell inactivation } \\
\text { - enzyme inactivation } \\
\text { - permeabilization } \\
\text { - extraction of fermentation products }\end{array}$ & $\begin{array}{l}\text { Frequent need for clean up } \\
\text { Difficulties in } \\
\text { - extracting polar analytes } \\
\text { - measurement and prediction of bio- } \\
\text { molecules solubility at varying pressure } \\
\text { and temperature for process optimiza- } \\
\text { tion } \\
\text { - dealing with natural samples }\end{array}$ & $\begin{array}{l}\text { Luque de Castro and Jiménez- } \\
\text { Carmona [74] } \\
\text { Khosravi-Darani et al. } \text { [53] } \\
\text { Cornish et al. } \text { [52] } \\
\text { Khosravi-Darani and Mozafari } \\
\text { [50] }\end{array}$ \\
\hline \multicolumn{4}{|l|}{ Types of SCF } \\
\hline Carbon dioxide & $\begin{array}{l}\text { Low toxicity and reactivity } \\
\text { Moderate critical temperature and pres- } \\
\text { sure } \\
\text { Good availability } \\
\text { Low cost } \\
\text { Non-flammable }\end{array}$ & Low dielectric constant & $\begin{array}{l}\text { Hejazi et al. }[49] \\
\text { Luque de Castro and Jiménez- } \\
\text { Carmona [74] }\end{array}$ \\
\hline Ammonia & $\begin{array}{l}\text { Better solvent strength than carbon } \\
\text { dioxide }\end{array}$ & $\begin{array}{l}\text { Difficult to pump } \\
\text { Chemically reactive } \\
\text { Dangerous for routine use }\end{array}$ & $\begin{array}{l}\text { Luque de Castro and Jiménez- } \\
\text { Carmona [74] }\end{array}$ \\
\hline Methanol & Excellent solvent & $\begin{array}{l}\text { High critical temperature } \\
\text { Liquid at ambient temperature, there- } \\
\text { fore complicates extraction process }\end{array}$ & $\begin{array}{l}\text { Luque de Castro and Jiménez- } \\
\text { Carmona [74] }\end{array}$ \\
\hline
\end{tabular}




\subsection{Cell fragility}

Increase in osmotic fragility during the accumulation of PHA are well documented with some microorganisms such as Azotobacter vinelandii UWD and recombinant $E$. coli (Table 1) [54-55]. The cell wall strength of these microorganisms could be compromised by modifying the composition of the growth medium. Cell fragility mechanism is not only restricted to Gram negative microorganisms but could be also exploited for Gram positive microorganisms [56]. Page and Cornish [55] demonstrated that the addition of fish peptone to the cultivation medium of $A$. vinelandii UWD led to the formation of large, pleomorphic, osmotically sensitive cells while high molecular weight $\mathrm{P}(3 \mathrm{HB})$ synthesis was enhanced. About $92 \%$ of $\mathrm{P}(3 \mathrm{HB})$ could be quickly extracted from the fragile cells with $1 \mathrm{~N}$ aqueous $\mathrm{NH}_{3}(\mathrm{pH}$ 11.4 ) at $45^{\circ} \mathrm{C}$ for $10 \mathrm{~min}$. The same phenomenon was observed with $B$. flexus [56]. The cells grown in the inorganic salts medium suffered from the absence of diaminopimelic acid (DAP) and decreased concentrations of other amino acids. DAP is an important component that formed cross bridge in the peptidoglycan and have a great influence on the structural stability of the cell wall. Up to $86-100 \%$ PHA recovery was obtained using hot chloroform or mild alkaline hydrolysis with cells cultivated in inorganic medium while only $32-56 \%$ of PHA was able to be extracted from cells grown in organic medium supplemented with peptone or yeast. Simple recovery method with mild extraction conditions could be developed based on cell fragility. However, it is necessary to balance the cell wall softening and cell wall integrity [55] in order to promote microbial growth with higher PHA content (Table 2).

\subsection{Flotation}

Ibrahim and Steinbüchel [57] investigated the recovery of $\mathrm{P}(3 \mathrm{HB})$ from a recently isolated bacterium, Zobellella denitrificans MW1 (Table 1). Simple extraction with various organic solvents followed by self-flotation of cell debris was tested. The cells were mixed with chloroform at $30^{\circ} \mathrm{C}$ for $72 \mathrm{~h}$ and later subjected to self-flotation of cell debris overnight at room temperature. This method allowed efficient recovery of $85 \%(\mathrm{w} / \mathrm{w})$ of $\mathrm{P}(3 \mathrm{HB})$ with purity of $98 \%$. This method should be cost effective as additional steps such as centrifugation and wastage of polymer during recovery could be avoided (Table 2) [57]. Adoption of green solvents together with flotation technique perhaps would add more benefits for the downstream processing of PHA. Previously, selective dissolved-air flotation was also applied to extract mcl-PHA from the cell debris of P. putida (Table 1) [58]. The main limitation of dissolved-air flotation is that it requires several consecutive flotation steps (Table 2).

\subsection{Aqueous two phase system (ATPS)}

Another potential method for the recovery of PHA was recently reported using B. flexus [37]. Aqueous two phase system (ATPS) is formed when two polymers at low concentrations (or of one polymer and an inorganic salt) that display incompatibility are mixed such that two immiscible phases coexist (Table 1) [59]. PHA containing B. flexus cells were subjected to enzymatic hydrolysis of Microbispora sp. cells filtrate and later introduced to polymer-salt ATPS system (Polyethylene glycol [PEG] 8000/phosphate, $\mathrm{pH} 8.0$ and $28^{\circ} \mathrm{C}$ ) reported recovery of high molecular weight PHA $\left(1 \cdot 10^{6}\right)$ with $97 \%$ purity. In addition, the authors highlighted that protease present in the Microbispora sp. cells filtrate was also isolated with several fold purity as a byproduct together with PHA [37]. Several factors, i.e. polymer molecular weight, concentration of polymer and salt, $\mathrm{pH}$, molecular mass, charge etc. have to be considered to choose a good ATPS recovery system. This technique is considered attractive because of short processing time, low material cost, low energy consumption, good resolution, high yield and a relatively high capacity [59-60]. However, ATPS is not yet being used in industrial scale due to problems such as robustness, reproducibility, absence of commercial kits to evaluate ATPS at bench scale as well as poor understanding of the mechanism (Table 2) [60].

\subsection{Gamma irradiation}

The effect of gamma irradiation on the wet cells of $B$. flexus to assist cell disruption for PHA recovery has also been investigated (Table 1) [61]. PHA recovery of $54 \%$ (based on biomass dry weight) was attained with the irradiated cells (10 kGy) subjected to chloroform extraction at room temperature in a short period. However, only $18-20 \%$ of PHA (based on biomass dry weight) was recovered from 
unirradiated cells exposed to chloroform extraction at $37^{\circ} \mathrm{C}$ and $150 \mathrm{rpm}$ for $2 \mathrm{~h}$. Gamma irradiation offers many advantages such as promoting optimal disruption of cells at low dosage of irradiation which enable easier recovery of PHA. Besides, retention of solvent solubility due to the low degree of cross-linking was reported [61]. Furthermore, radiation induced cell disruption is independent of any chemicals resulting in relatively contamination free process. The major setbacks of this technique are the length of irradiation time and the initial investment cost that hinders large scale applications (Table 2) [62].

The chemicals and the conditions used for each recovery technique described above are summarized in Table 4. This table clearly shows that chemicals such as organic solvents, alkaline or acidic solutions and surfactants are widely used in most of the PHA recovery methods and have been tested under different working conditions. Even with fragile cells, mild chemicals such as aqueous $\mathrm{NH}_{3}$ are still required in order to completely rupture the cells. In contrast, enzymatic digestion seems to be more environmentally friendly. However, pure enzymes are costly. In order to address the cost issue, some researchers have used whole microbial cultures as the source of the enzymes. It has been reported that the use of Microbispora sp. culture instead of pure enzymes to hydrolyze $S$. meliloti cells and was found to be promising. Some methods like bead mill, highpressure homogenization and supercritical fluid disruption are also environmentally friendly since no chemicals are involved in the PHA recovery process. The use of gamma irradiation has to be extensively studied to prove its efficiency.

\section{Large scale production of PHA}

The underlying challenge for the commercialization of PHA is the high production cost which arises predominantly due to expensive purification technologies of PHA. Still, many attempts have been made on the development of simple fermentation strategies as well as modification of recovery techniques in order to scale-up the PHA production.

Table 4. Various chemicals and conditions used in PHA recovery techniques

\begin{tabular}{|c|c|c|c|}
\hline Recovery method & Strain & Chemical(s) and conditions & Reference \\
\hline Solvent extraction & Cupriavidus necator DSM 545 & $\begin{array}{l}\text { 1,2-propylene carbonate, } 130^{\circ} \mathrm{C} \text { for } \\
30 \text { min }\end{array}$ & Fiorese et al. [25] \\
\hline Digestion with surfactant & Recombinant Escherichia coli & $\begin{array}{l}\text { Sodium dodecyl sulfate (SDS), } \\
30^{\circ} \mathrm{C}, 1 \mathrm{~h}\end{array}$ & Choi and Lee [54] \\
\hline $\begin{array}{l}\text { Digestion with sodium } \\
\text { hypochlorite }\end{array}$ & $\begin{array}{l}\text { C. necator } \\
\text { Recombinant E. coli }\end{array}$ & Sodium hypochlorite, $30^{\circ} \mathrm{C}, 1 \mathrm{~h}$ & Hahn et al. [69] \\
\hline $\begin{array}{l}\text { Digestion with surfactant- } \\
\text { sodium hypochlorite }\end{array}$ & Azotobacter chroococcum G-3 & $\begin{array}{l}\mathrm{SDS}, 55^{\circ} \mathrm{C}, 15 \mathrm{~min} \text { followed by } \\
\text { sodium hypochlorite, } 30^{\circ} \mathrm{C}, 3 \mathrm{~min}\end{array}$ & Dong and Sun [28] \\
\hline $\begin{array}{l}\text { Digestion with surfactant- } \\
\text { chelate }\end{array}$ & Sinorhizobium meliloti & $\begin{array}{l}\text { Triton } \mathrm{X}-100 \text { mixed with EDTA, } \\
50^{\circ} \mathrm{C}, 10 \mathrm{~min}\end{array}$ & $\begin{array}{l}\text { Lakshman and Shamala } \\
{[34]}\end{array}$ \\
\hline $\begin{array}{l}\text { Dispersion of sodium hypochlo- } \\
\text { rite and chloroform }\end{array}$ & Bacillus cereus SPV & $\begin{array}{l}50 \mathrm{ml} \text { chloroform : } 50 \mathrm{ml} \text { sodium } \\
\text { hypochlorite, } 38^{\circ} \mathrm{C}, 1 \mathrm{~h}\end{array}$ & Valappil et al. [31] \\
\hline Selective dissolution by protons & Cell slurry & $\begin{array}{l}0.1 \mathrm{M} \mathrm{H}_{2} \mathrm{SO}_{4}, 100^{\circ} \mathrm{C}, 120 \mathrm{~min} \text { fol- } \\
\text { lowed by } \mathrm{pH} \text { adjustment (pH 10) } \\
\text { and decolorization using bleaching } \\
\text { solution, } 2 \mathrm{~h} \text {, room temperature }\end{array}$ & $\mathrm{Yu}[22]$ \\
\hline Enzymatic digestion & S. meliloti & $\begin{array}{l}\text { Microbispora } \text { sp. culture-chloro- } \\
\text { form }\end{array}$ & $\begin{array}{l}\text { Lakshman and Shamala } \\
{[34]}\end{array}$ \\
\hline Bead mill & Alcaligenes latus & $\begin{array}{l}\text { Bead diameter of } 512 \mu \mathrm{m} \text {, bead } \\
\text { loading of } 85 \%, 2800 \mathrm{rpm}\end{array}$ & Tamer et al. $[23]$ \\
\hline High pressure homogenization & Methylobacterium sp V49 & $\begin{array}{l}\text { Operating pressure } 400 \mathrm{~kg} \cdot \mathrm{cm}^{-2} \text {, } \\
5 \%(\mathrm{w} / \mathrm{v}) \mathrm{SDS}\end{array}$ & Ghatnekar et al. [48] \\
\hline Supercritical fluid & C. necator & $\begin{array}{l}\text { Supercritical } \mathrm{CO}_{2}, 100 \mathrm{~min} \text {, } \\
200 \mathrm{~atm}, 40^{\circ} \mathrm{C} \text { and } 0.2 \mathrm{ml} \text { of } \\
\text { methanol }\end{array}$ & Hejazi et al. [49] \\
\hline Cell fragility & Azotobacter vinelandii UWD & $\begin{array}{l}1 \mathrm{~N} \text { aqueous } \mathrm{NH}_{3}(\mathrm{pH} 11.4), 45^{\circ} \mathrm{C} \\
10 \mathrm{~min}\end{array}$ & Page and Cornish [55] \\
\hline Self flotation of cell debris & Zobellella denitrificans MW1 & $\begin{array}{l}\text { Chloroform, } 30^{\circ} \mathrm{C}, 72 \mathrm{~h} \text {, Self flota- } \\
\text { tion of cell debris overnight at } \\
\text { room temperature }\end{array}$ & $\begin{array}{l}\text { Ibrahim and Steinbüchel } \\
{[57]}\end{array}$ \\
\hline Aqueous two phase system & B. flexus & $\begin{array}{l}\text { Polyethylene glycol [PEG] } \\
8000 / \text { phosphate, pH } 8.0 \text { and } 28^{\circ} \mathrm{C} \text {, } \\
30 \mathrm{~min}\end{array}$ & Divyashree et al. [37] \\
\hline Gamma irradiation & B. flexus & Radiation doses of 10-40 kGy & $\begin{array}{l}\text { Divyashree and Shamala } \\
\text { [61] }\end{array}$ \\
\hline
\end{tabular}


Chen et al. [63] investigated the accumulation of poly(3-hydroxybutyrate-co-3-hydroxyhexanoate) [P(3HB-co-3HHx $)]$ from Aeromonas hydrophila $4 \mathrm{AK} 4$, which was cultivated in a 200001 fermentor using lauric acid as the carbon source under phosphorus limitation. A maximum cell dry weight (CDW) of $50 \mathrm{~g} / 1$ and PHA content of $50 \mathrm{wt} \%$ was achieved by optimizing the carbon source concentrations and the time point for applying phosphorus limitation. The cultivated cells were initially precipitated by adding $1 \% \mathrm{Na}_{2} \mathrm{HPO}_{4}, 1 \% \mathrm{CaCl}_{2}$, and $100 \mathrm{ppm}$ polyacrylamide into the fermentor and filter-pressed to remove water. The cakes of cells were then freeze-dried and ground into powder. PHA extraction was carried out by gently stirring 200 $500 \mathrm{~kg}$ of dried cells at $60^{\circ} \mathrm{C}$ for $2 \mathrm{~h}$ in 300001 extraction tank containing 50001 of ethyl acetate. The polymer solution was passed through a metal filter and centrifuged to remove cell debris before performing precipitation using 150001 of hexane or heptane. Finally, the flocculants of polymer were collected using filter press followed by washing with ethanol before being vacuum-dried. The use of solvents such as ethyl acetate, hexane or heptane were thought to reduce the PHA recovery cost, which accounted to more than $50 \%$ of the overall PHA production cost since the solvents could be recovered by distillation. The idea of acetone-water based PHA extraction was proposed to make the recovery process more economically feasible. Recently, large-scale cultivation of $P$. putida GPo1 and recovery of poly(3-hydroxyoctanoate) (PHO) were studied [64]. As high as $53 \mathrm{~g} / \mathrm{l}$ of CDW with $60 \mathrm{wt} \%$ PHA accumulation was obtained by manipulating the inoculum size (1-2\%), $\mathrm{pH}$ of the medium as well as carbon (octanoic acid) and nitrogen (ammonium octanoate) source concentrations. Continuous separation together with continuous cell release from the separator was used to separate the cells before the freeze drying process. The recovery process involved $25 \mathrm{~kg}$ freeze-dried cells in 2501 of acetone which was later concentrated to 751 . Acetone as an alternative to chlorinated solvents, is an inexpensive, relatively safe and readily available renewable resource, which can be produced as a byproduct of microbial fermentation. The acetone recovered through distillation was used several times to lower the extraction costs. The recycling strategy applied in this research [64] was similar to the work described by Chen and co-workers [63]. Precipitation solvents composed of $70 \%(\mathrm{v} / \mathrm{v})$ methanol and $70 \%(\mathrm{v} / \mathrm{v})$ ethanol has also been evaluated. This mixture overcomes the problem of 10 volumes of PHA non-solvent consumption for precipitation of the polymer when acetone was used as a solvent. Instead, 1:1 (v/v) ratio of the mixture to PHO concentrate was sufficient to isolate $94 \%$ of PHO with $99 \%$ purity [64]. Comparison of the two PHA recovery methods reported using different types of solvents suggests the latter to have more profound economical impacts. The best option is to reduce the extensive use of solvents. If acetonewater based recovery method could be developed and extended for extraction of various types of PHA, it will be possible to reduce the extraction cost.

\section{Summary and outlook}

Microbial PHA is a potential renewable biopolymer with properties closely resembling some common petrochemical plastics. Because of the vast range of structurally different monomers that can be polymerized by microbes, a wide range of material properties can be achieved. Metabolic engineering and high-density cell culture technologies can be exploited for the large-scale production of specified PHA. Based on information reported in the literatures, it is not impossible to grow bacterial cells up to a density of $150 \mathrm{~g} / \mathrm{l}$ with a PHA content of more than $80 \mathrm{wt} \%$ of the cell dry weight. However, the extraction and purification of the PHA granules from the cell biomass is a challenging task especially when one considers the use of environmentally hazardous chemicals as an unacceptable option in the production of eco-friendly materials. This paper has reviewed the various types of methods that have been tested for the extraction and purification of PHA granules from microbial cell biomass. While cost is a major deciding factor in the selection of a suitable method, it is generally expected that the usage of strong chemicals and solvents need to be minimized. The final intended application for the PHA will determine the degree of purity of the PHA granules. For example, in medical applications it is absolutely necessary that the PHA should be free from bacterial endotoxins and other contaminating chemicals and solvents. On the other hand, if the PHA is intended for applications such as mulching 
film or garbage bags, a lower degree of purity may be acceptable. Regardless of its final applications, the molecular weights of the recovered PHA should be sufficiently high. This is because the thermal processing of the PHA would result in the reduction of its molecular weights to some extent. Therefore, it is important to have PHA resins with as high a molecular weight as possible. In order to obtain PHA with a high degree of purity, more stringent recovery process is needed. This often results in PHA with lower molecular weights. In addition, the recovery yield will also be lower. Therefore, the challenge in the recovery process is to maintain the original molecular weights while not compromising the degree of purity for various applications. These criteria have to be achieved in an environmentally friendly manner. Finally, and most importantly, the cost of the recovery process should be economically feasible. Together with PHA recovery techniques, fermentation strategies also should be governed. Development of strains that could effectively overproduce PHA from various unprocessed, cheap and renewable carbon sources also plays an important role in lowering the cost of PHA production. Commercialization of PHA could be accomplished by broadening the PHA application areas and exploring more high value added usage such as medical applications.

\section{Acknowledgements}

B. Kunasundari gratefully acknowledges USM Fellowship for financial support. We also thank Yoga Sugama Salim and Rathi Devi Nair for their help in editing this manuscript.

\section{References}

[1] Lazarevic D., Aoustin E., Buclet N., Brandt N.: Plastic waste management in the context of a European recycling society: Comparing results and uncertainties in a life cycle perspective. Resources, Conservation and Recycling, 55, 246-259 (2010).

DOI: $10.1016 /$ j.resconrec.2010.09.014

[2] Chen G-Q.: A microbial polyhydroxyalkanoates (PHA) based bio- and materials industry. Chemical Society Reviews, 38, 2434-2446 (2009). DOI: $10.1039 / \mathrm{b} 812677 \mathrm{c}$

[3] Sudesh K., Abe H., Doi Y.: Synthesis, structure and properties of polyhydroxyalkanoates: Biological polyesters. Progress in Polymer Science, 25, 1503-1555 (2000).

DOI: 10.1016/S0079-6700(00)00035-6
[4] Taguchi S., Yamada M., Matsumoto K., Tajima K., Satoh Y., Munekata M., Ohno K., Kohda K., Shimamura T., Kambe H., Obata S.: A microbial factory for lactate-based polyesters using a lactate-polymerizing enzyme. Proceedings of the National Academy of Sciences of the United States of America, 105, 1732317327 (2008).

DOI: $10.1073 /$ pnas.0805653105

[5] Yamada M., Matsumoto K., Nakai T., Taguchi S.: Microbial production of lactate-enriched poly[(R)-lactate-co-(R)-3-hydroxybutyrate] with novel thermal properties. Biomacromolecules, 10, 677-681 (2009). DOI: $10.1021 / \mathrm{bm} 8013846$

[6] Shozui F., Matsumoto K., Nakai T., Yamada M., Taguchi S.: Biosynthesis of novel terpolymers poly (lactate-co-3-hydroxybutyrate-co-3-hydroxyvalerate)s in lactate-overproducing mutant Escherichia coli JW0885 by feeding propionate as a precursor of 3hydroxyvalerate. Applied Microbiology and Biotechnology, 85, 949-954 (2009).

DOI: $10.1007 / \mathrm{s} 00253-009-2100-\mathrm{y}$

[7] Koller M., Hesse P., Kutschera C., Bona R., Nascimento J., Ortega S., Agnelli J. A., Braunegg G.: Sustainable embedding of the bioplastic poly-(3-hydroxybutyrate) into the sugarcane industry: Principles of a future-oriented technology in Brazil. in 'Polymers Opportunities and risks II: Sustainability, product design and processing' (eds.: Eyerer P., Weller M., Hübner C.) Springer-Verlag Berlin Heidelberg, New York, Vol 12, 81-96 (2009).

DOI: $10.1007 / 698200911$

[8] Loo C-Y., Lee W-H., Tsuge T., Doi Y., Sudesh K.: Biosynthesis and characterization of poly(3-hydroxybutyrate-co-3- hydroxyhexanoate) from palm oil products in a Wautersia eutropha mutant. Biotechnology Letters, 27, 1405-1410 (2005).

DOI: $10.1007 / \mathrm{s} 10529-005-0690-8$

[9] Lee W-H., Loo C-Y., Nomura C. T., Sudesh K.: Biosynthesis of polyhydroxyalkanoate copolymers from mixtures of plant oils and 3-hydroxyvalerate precursors. Bioresource Technology, 99, 6844-6851 (2008).

DOI: $10.1016 /$ j.biortech.2008.01.051

[10] Ng K-S., Ooi W-Y., Goh L-K., Shenbagarathai R., Sudesh K.: Evaluation of jatropha oil to produce poly (3-hydroxybutyrate) by Cupriavidus necator H16. Polymer Degradation and Stability, 95, 1365-1369 (2010). DOI: 10.1016/j.polymdegradstab.2010.01.021

[11] Kahar P., Tsuge T., Taguchi K., Doi Y.: High yield production of polyhydroxyalkanoates from soybean oil by Ralstonia eutropha and its recombinant strain. Polymer Degradation and Stability, 83, 79-86 (2004). DOI: 10.1016/S0141-3910(03)00227-1

[12] Sudesh K., Bhubalan K., Chuah J-A., Kek Y-K., Kamilah H., Sridewi N., Lee Y-F.: Synthesis of polyhydroxyalkanoate from palm oil and some new applications. Applied Microbiology and Biotechnology, 89, 1373-1386 (2010). 
[13] Akiyama M., Tsuge T., Doi Y.: Environmental life cycle comparison of polyhydroxyalkanoates produced from renewable carbon resources by bacterial fermentation. Polymer Degradation and Stability, 80, 183194 (2003).

DOI: $10.1016 / \mathrm{S} 0141-3910(02) 00400-7$

[14] Sudesh K., Gan Z., Maehara A., Doi Y.: Surface structure, morphology and stability of polyhydroxyalkanoate inclusions characterised by atomic force microscopy. Polymer Degradation and Stability, 77, 77-85 (2002). DOI: 10.1016/S0141-3910(02)00081-2

[15] Sudesh K., Maehara A., Gan Z., Iwata T., Doi Y.: Direct observation of polyhydroxyalkanoate granuleassociated-proteins on native granules and on poly(3hydroxybutyrate) single crystals by atomic force microscopy. Polymer Degradation and Stability, 83, 281-287 (2004). DOI: $10.1016 / \mathrm{S} 0141-3910(03) 00273-8$

[16] Khanna S., Srivastava A. K.: Recent advances in microbial polyhydroxyalkanoates. Process Biochemistry, 40, 607-619 (2005).

DOI: $10.1016 /$ j.procbio.2004.01.053

[17] Jacquel N., Lo C-W., Wei Y-H., Wu H-S., Wang S. S.: Isolation and purification of bacterial poly(3-hydroxyalkanoates). Biochemical Engineering Journal, 39, 15-27 (2008).

DOI: $10.1016 /$ j.bej.2007.11.029

[18] Ramsay J. A., Berger E., Voyer R., Chavarie C., Ramsay B. A.: Extraction of poly-3-hydroxybutyrate using chlorinated solvents. Biotechnology Techniques, 8, 589-594 (1994).

DOI: $10.1007 / \mathrm{BF} 00152152$

[19] Lafferty R. M., Heinzle E.: Use of cyclic carbonic acid esters as solvents for poly-( $\beta$-hydroxybutyric acid). U.S. Patent 4140741, USA (1979).

[20] Jiang X., Ramsay J. A., Ramsay B. A.: Acetone extraction of mcl-PHA from Pseudomonas putida KT2440. Journal of Microbiological Methods, 67, 212-219 (2006).

DOI: $10.1016 /$ j.mimet.2006.03.015

[21] Yu J., Chen L. X. L.: Cost-effective recovery and purification of polyhydroxyalkanoates by selective dissolution of cell mass. Biotechnology Progress, 22, 547-553 (2006).

DOI: 10.1021/bp050362g

[22] Yu J.: Recovery and purification of polyhydroxyalkanoates. U.S. Patent 7514525, USA (2009).

[23] Tamer I. M., Moo-Young M., Chisti Y.: Disruption of Alcaligenes latus for recovery of poly( $\beta$-hydroxybutyric acid): Comparison of high-pressure homogenization, bead milling, and chemically induced lysis. Industrial and Engineering Chemistry Research, 37, $1807-$ 1814 (1998).

DOI: $10.1021 /$ ie9707432
[24] McChalicher C. W. J., Srienc F., Rouse D. P.: Solubility and degradation of polyhydroxyalkanoate biopolymers in propylene carbonate. AIChE Journal, 56, 16161625 (2010).

DOI: 10.1002/aic.12087

[25] Fiorese M. L., Freitas F., Pais J., Ramos A. M., de Aragão G. M. F., Reis M. A. M.: Recovery of polyhydroxybutyrate (PHB) from Cupriavidus necator biomass by solvent extraction with 1,2-propylene carbonate. Engineering in Life Sciences, 9, 454-461 (2009). DOI: $10.1002 /$ elsc.200900034

[26] Wampfler B., Ramsauer T., Rezzonico S., Hischier R., Köhling R., Thöny-Meyer L., Zinn M.: Isolation and purification of medium chain length poly(3-hydroxyalkanoates) (mcl-PHA) for medical applications using nonchlorinated solvents. Biomacromolecules, 11, 27162723 (2010). DOI: $10.1021 / \mathrm{bm} 1007663$

[27] Ramsay J. A., Berger E., Ramsay B. A., Chavarie C.: Recovery of poly-3-hydroxyalkanoic acid granules by a surfactant-hypochlorite treatment. Biotechnology Techniques, 4, 221-226 (1990). DOI: $10.1007 / \mathrm{BF} 00158833$

[28] Dong Z., Sun X.: A new method of recovering polyhydroxyalkanoate from Azotobacter chroococcum. Chinese Science Bulletin, 45, 252-256 (2000).

DOI: $10.1007 / \mathrm{BF} 02884685$

[29] Hahn S. K., Chang Y. K., Kim B. S., Chang H. N.: Optimization of microbial poly(3-hydroxybutyrate) recovery using dispersions of sodium hypochlorite solution and chloroform. Biotechnology and Bioengineering, 44, 256-261 (1994).

DOI: $10.1002 /$ bit.260440215

[30] Hahn S. K., Chang Y. K., Kim B. S., Lee K. M., Chang H. N.: The recovery of poly(3-hydroxybutyrate) by using dispersions of sodium hypochlorite solution and chloroform. Biotechnology Techniques, 7, 209-212 (1993).

DOI: $10.1007 / \mathrm{BF} 02566149$

[31] Valappil S. P., Misra S. K., Boccaccini A. R., Keshavarz T., Bucke C., Roy I.: Large-scale production and efficient recovery of PHB with desirable material properties, from the newly characterised Bacillus cereus SPV. Journal of Biotechnology, 132, 251-258 (2007). DOI: $10.1016 /$ j.jbiotec.2007.03.013

[32] Chen Y., Chen J., Yu C., Du G., Lun S.: Recovery of poly-3-hydroxybutyrate from Alcaligenes eutrophus by surfactant-chelate aqueous system. Process Biochemistry, 34, 153-157 (1999). DOI: $10.1016 / \mathrm{S} 0032-9592(98) 00082-\mathrm{X}$

[33] Chen Y., Yang H., Zhou Q., Chen J., Gu G.: Cleaner recovery of poly(3-hydroxybutyric acid) synthesized in Alcaligenes eutrophus. Process Biochemistry, 36, 501-506 (2001). DOI: 10.1016/S0032-9592(00)00225-9 
[34] Lakshman K., Shamala T. R.: Extraction of polyhydroxyalkanoate from Sinorhizobium meliloti cells using Microbispora sp. culture and its enzymes. Enzyme and Microbial Technology, 39, 1471-1475 (2006).

DOI: $10.1016 /$ j.enzmictec.2006.03.037

[35] Holmes P. A., Lim G. B.: Separation process. U.S. Patent 4910145, USA (1990).

[36] Yasotha K., Aroua M. K., Ramachandran K. B., Tan I. K. P.: Recovery of medium-chain-length polyhydroxyalkanoates (PHAs) through enzymatic digestion treatments and ultrafiltration. Biochemical Engineering Journal, 30, 260-268 (2006).

DOI: $10.1016 /$ j.bej.2006.05.008

[37] Divyashree M. S., Shamala T. R., Rastogi N. K.: Isolation of polyhydroxyalkanoate from hydrolyzed cells of Bacillus flexus using aqueous two-phase system containing polyethylene glycol and phosphate. Biotechnology and Bioprocess Engineering, 14, 482-489 (2009). DOI: $10.1007 / \mathrm{s} 12257-008-0119-\mathrm{Z}$

[38] Middelberg A. P. J.: Process-scale disruption of microorganisms. Biotechnology Advances, 13, 491-551 (1995). DOI: 10.1016/0734-9750(95)02007-P

[39] Kapritchkoff F. M., Viotti A. P., Alli R. C. P., Zuccolo M., Pradella J. G. C., Maiorano A. E., Miranda E. A., Bonomi A.: Enzymatic recovery and purification of polyhydroxybutyrate produced by Ralstonia eutropha. Journal of Biotechnology, 122, 453-462 (2006).

DOI: $10.1016 /$ j.jbiotec.2005.09.009

[40] Harrison S. T. L.: Bacterial cell disruption: A key unit operation in the recovery of intracellular products. Biotechnology Advances, 9, 217-240 (1991). DOI: $10.1016 / 0734-9750(91) 90005-\mathrm{G}$

[41] Bury D., Jelen P., Kaláb M.: Disruption of Lactobacillus delbrueckii ssp. bulgaricus 11842 cells for lactose hydrolysis in dairy products: A comparison of sonication, high-pressure homogenization and bead milling. Innovative Food Science and Emerging Technologies, 2, 23-29 (2001).

DOI: 10.1016/S1466-8564(00)00039-4

[42] Park P. K., Kim E. Y., Chu K. H.: Chemical disruption of yeast cells for the isolation of carotenoid pigments. Separation and Purification Technology, 53, 148-152 (2007).

DOI: 10.1016/j.seppur.2006.06.026

[43] Balasundaram B., Harrison S. T. L.: Influence of the extent of disruption of Bakers' yeast on protein adsorption in expanded beds. Journal of Biotechnology, 133, 360-369 (2008).

DOI: $10.1016 /$ j.jbiotec.2007.07.724

[44] Doucha J., Lívanský K.: Influence of processing parameters on disintegration of Chlorella cells in various types of homogenizers. Applied Microbiology and Biotechnology, 81, 431-440 (2008).

DOI: $10.1007 / \mathrm{s} 00253-008-1660-6$
[45] Geciova J., Bury D., Jelen P.: Methods for disruption of microbial cells for potential use in the dairy industry - A review. International Dairy Journal, 12, 541553 (2002).

DOI: 10.1016/S0958-6946(02)00038-9

[46] Kelly W. J., Muske K. R.: Optimal operation of highpressure homogenization for intracellular product recovery. Bioprocess and Biosystems Engineering, 27, 2537 (2004).

DOI: $10.1007 / \mathrm{s} 00449-004-0378-9$

[47] Diels A. M. J., Michiels C. W.: High-pressure homogenization as a non-thermal technique for the inactivation of microorganisms. Critical Reviews in Microbiology, 32, 201-216 (2006).

DOI: $10.1080 / 10408410601023516$

[48] Ghatnekar M. S., Pai J. S., Ganesh M.: Production and recovery of poly-3-hydroxybutyrate from Methylobacterium sp V49. Journal of Chemical Technology and Biotechnology, 77, 444-448 (2002).

DOI: $10.1002 / \mathrm{jctb} .570 . \mathrm{abs}$

[49] Hejazi P., Vasheghani-Farahani E., Yamini Y.: Supercritical fluid disruption of Ralstonia eutropha for poly ( $\beta$-hydroxybutyrate) recovery. Biotechnology Progress, 19, 1519-1523 (2003). DOI: $10.1021 / \mathrm{bp} 034010 \mathrm{q}$

[50] Khosravi-Darani K., Mozafari M. R.: Supercritical fluids technology in bioprocess industries: A review. Journal of Biochemical Technology, 2, 144-152 (2009).

[51] Khosravi-Darani K., Vasheghani-Farahani E., Yamini Y., Bahramifar N.: Solubility of poly( $\beta$-hydroxybutyrate) in supercritical carbon dioxide. Journal of Chemical and Engineering Data, 48, 860-863 (2003).

DOI: $10.1021 / \mathrm{je} 020168 \mathrm{v}$

[52] Cornish K., Martin J. A., Marentis R. T., Plamthottam S.: Extraction and fractionation of biopolymers and resins from plant materials. U.S. Patent 7259231, USA (2007).

[53] Khosravi-Darani K., Vasheghani-Farahani E., Shojaosadati S. A., Yamini Y.: Effect of process variables on supercritical fluid disruption of Ralstonia eutropha cells for poly(R-hydroxybutyrate) recovery. Biotechnologyl Progress, 20, 1757-1765 (2004).

DOI: $10.1021 / \mathrm{bp} 0498037$

[54] Choi J-I., Lee S. Y.: Efficient and economical recovery of poly(3-hydroxybutyrate) from recombinant Escherichia coli by simple digestion with chemicals. Biotechnology and Bioengineering, 62, 546-553 (1999).

DOI: 10.1002/(SICI)1097-0290(19990305)62:5<546:: AID-BIT6>3.0.CO;2-0

[55] Page W. J., Cornish A.: Growth of Azotobacter vinelandii UWD in fish peptone medium and simplified extraction of poly- $\beta$-hydroxybutyrate. Applied and Environmental Microbiology, 59, 4236-4244 (1993). 
[56] Divyashree M. S., Shamala T. R.: Extractability of polyhydroxyalkanoate synthesized by Bacillus flexus cultivated in organic and inorganic nutrient media. Indian Journal of Microbiology, 50, 63-69 (2010). DOI: 10.1007/s12088-010-0013-1

[57] Ibrahim M. H. A., Steinbüchel A.: Poly(3-hydroxybutyrate) production from glycerol by Zobellella denitrificans MW1 via high-cell-density fed-batch fermentation and simplified solvent extraction. Applied and Environmental Microbiology, 75, 6222-6231 (2009). DOI: 10.1128/AEM.01162-09

[58] van Hee P., Elumbaring A. C. M. R., van der Lans R. G. J. M., Van der Wielen L. A. M.: Selective recovery of polyhydroxyalkanoate inclusion bodies from fermentation broth by dissolved-air flotation. Journal of Colloid and Interface Science, 297, 595-606 (2006). DOI: 10.1016/j.jcis.2005.11.019

[59] Yang S., Huang Z., Jiang Z., Li L.: Partition and purification of a thermostable xylanase produced by Paecilomyces thermophila in solid-state fermentation using aqueous two-phase systems. Process Biochemistry, 43, 56-61 (2008).

DOI: $10.1016 /$ j.procbio.2007.10.013

[60] Rito-Palomares M.: Practical application of aqueous two-phase partition to process development for the recovery of biological products. Journal of Chromatography $\mathrm{B}, \mathbf{8 0 7}, 3-11$ (2004).

DOI: $10.1016 /$ j.jchromb.2004.01.008

[61] Divyashree M. S., Shamala T. R.: Effect of gamma irradiation on cell lysis and polyhydroxyalkanoate produced by Bacillus flexus. Radiation Physics and Chemistry, 78, 147-152 (2009).

DOI: $10.1016 /$ j.radphyschem.2008.08.010

[62] Bhattacharya A.: Radiation and industrial polymers. Progress in Polymer Science, 25, 371-401 (2000). DOI: 10.1016/S0079-6700(00)00009-5

[63] Chen G. Q., Zhang G., Park S. J., Lee S. Y.: Industrial scale production of poly(3-hydroxybutyrate-co-3hydroxyhexanoate). Applied Microbiology and Biotechnology, 57, 50-55 (2001).

DOI: $10.1007 / \mathrm{s} 002530100755$

[64] Elbahloul Y., Steinbüchel A.: Large-scale production of poly(3-hydroxyoctanoic acid) by Pseudomonas putida GPol and a simplified downstream process. Applied and Environmental Microbiology, 75, 643651 (2009).

DOI: 10.1128/AEM.01869-08
[65] Narasimhan K., Cearley A. C., Gibson M. S., Welling S. J.: Process for the solvent-based extraction of polyhydroxyalkanoates from biomass. U.S. Patent 7378266 , USA (2008).

[66] Zinn M., Weilenmann H-U., Hany R., Schmid M., Egli T.: Tailored synthesis of poly([R]-3-hydroxybutyrateco-3-hydroxyvalerate) (PHB/HV) in Ralstonia eutropha DSM 428. Acta Biotechnologica, 23, 309-316 (2003). DOI: 10.1002/abio.200390039

[67] Mantelatto P. E., Durao N. A. S.: Process for extracting and recovering polyhydroxyalkanoates (PHAs) from cellular biomass. U.S. Patent 20080193987, USA (2008).

[68] Lee K. M., Chang H. N., Chang Y. K., Kim B. S., Hahn S. K.: The lysis of gram-negative Alcaligenes eutrophus and Alcaligenes latus by palmitoyl carnitine. Biotechnology Techniques, 7, 295-300 (1993). DOI: $10.1007 / \mathrm{BF} 00150902$

[69] Hahn S. K., Chang Y. K., Lee S. Y.: Recovery and characterization of poly(3-hydroxybutyric acid) synthesized in Alcaligenes eutrophus and recombinant Escherichia coli. Applied and Environmental Microbiology, 61, 34-39 (1995).

[70] Berger E., Ramsay B. A., Ramsay J. A., Chavarie C., Braunegg G.: PHB recovery by hypochlorite digestion of non-PHB biomass. Biotechnology Techniques, 3, 227- 232 (1989).

DOI: $10.1007 / \mathrm{BF} 01876053$

[71] Kathiraser Y., Aroua M. K., Ramachandran K. B., Tan I. K. P.: Chemical characterization of medium-chainlength polyhydroxyalkanoates (PHAs) recovered by enzymatic treatment and ultrafiltration. Journal of Chemical Technology and Biotechnology, 82, 847855 (2007). DOI: $10.1002 /$ jctb. 1751

[72] Noda I.: Process for recovering polyhydroxyalkanotes using air classification. U.S. Patent 5849854, USA (1998).

[73] Jung I. L., Phyo K. H., Kim K. C., Park H. K., Kim I. G.: Spontaneous liberation of intracellular polyhydroxybutyrate granules in Escherichia coli. Research in Microbiology, 156, 865-873 (2005). DOI: $10.1016 /$ j.resmic.2005.04.004

[74] Luque de Castro M. D., Jiménez-Carmona M. M.: Where is supercritical fluid extraction going? TrAC Trends in Analytical Chemistry, 19, 223-228 (2000). DOI: 10.1016/S0165-9936(99)00228-9 